\title{
The Analysis of Anti-heroic Characteristics of Eggsy in Kingsman from the Perspective of Cooperative Principle
}

\author{
LIU Jing, MA Wen-li \\ School of Foreign Language, Wuhan University of Technology, Wuhan, China
}

\begin{abstract}
Cooperative Principle was first proposed by American linguist H. P. Grice. It is the regularity in conversation, which means make your conversational contribution such as is required, at the stage at which it occurs, by the accepted purpose or direction of the talk exchange in which you are engaged. Anti-hero is a concept opposed to a traditional hero, whose characteristics are totally contrary to traditional aestheticism. Lack of the noble beliefs and goals in life, anti-heroes are often pessimistic and eccentric. The movie Kingsman is directed by Matthew Vaughn, whose story is aroundthe protagonist Eggsy. The focus of study is characteristic subversion from a common person to a hero. At present, most of the researches at home and abroad only focus on the characteristics of anti-heroes or from the aspect of violenceaesthetics or the film literature analysis, there is few analysis of the film language charm, and even fewer studies analyzethis movie from the perspective of linguistics. In this paper, the corpus is selected from Kingsman.Firstly, it introduces the concept of CP and the anti-hero as well as the related researches in recent years. It aims to analyze the anti-heroic characteristics of Eggsy through literature and theoretical analysis, and CP as a theoretical framework. Therefore the literary significance of Kingsman can be found and "heroes" will be redefined.
\end{abstract}

Keywords: CP, anti-hero, Kingsman

\section{Introduction}

Matthew Vaughn was born in March 7th, 1971, London. For him, Kingsman is his confession to spy movies. Vaughn has his own understanding of Kingsman which is as a film adapted by comics. On the one hand, he directed the movie according to reality, on the other hand, he constantly revised the story surrealistically, making the film endlessly wandering between comics and movies and blurring the boundaries between these two, so that it can apart from other movies.

The movie Kingsman tells a story of a special boy Eggsy. When Eggsy's father was on a secret mission in the Middle East, his father dead in order to protect Harry. Owing to his family's misfortune, his stepfather's barbarism and his self-indulgences, he degenerates from aexcellent teenager into a thief. Encouraged by Harry, he began to accept a special training and testin order to become the next Kingsman. During the challenge, he

LIU Jing, Master of Art, Master Student, School of Foreign Language, Wuhan University of Technology.

MA Wen-li, Ph.D., Professor, School of Foreign Language, Wuhan University of Technology. 
showed unusual excellence. After Harry's killing, he formed a new team with instructor Merlin and Lancelot and set out on a journey to save the world from Valentine's plot.

According to Grice's point of view, our conversational communication is not usually made up of a series of intermittent remarks, or it would be unreasonable if they do so; at least to some extent, they have characteristic cooperative efforts; and to some extent, each participant all recognizes the common goals or assets of the goals, or at least the directions accepted by both parties (戴炜栋 \& 何兆熊, 2002, p. 288). Later on he proposed regularity about conservation, which is called the CP. This theory can be well used to analyze what others say in order to predict his intended meaning. While a majority of anti-heroic characters hesitate to press forward when they meet difficulties; even they have a ridiculous way of life, which completely loses the sense of lofty that traditional heroes have. This personality is the key point of Eggsy.

\section{Literature Review}

\subsection{Cooperative Principle}

The CP was first put forward by the American language philosopher Grice in his speech Logic and conversation at Harvard University in 1967. Grice believes that both parties seem to follow a certain principleconsciously or unintentionally in the process of communication, in order to cooperate with others effectively and accomplish the task of communication (胡壮麟, 1980, p. 240). So, Grice proposed the CP about the regularity in conversation, "which means make your conversational contribution such as is required, at the stage at which it occurs, by the accepted purpose or direction of the talk exchange in which you are engaged" (胡壮麟, 1980, p. 245). There are four maxims in total: (1)The maxim of quantity; (2)The maxim of quality; (3)The maxim of relation; (4)The maxim of manner-be perspicuous

For a better understanding, Grice proposed the second major theory in pragmatics, namely the theory of conversational implication in Logic and Conversation. According to P. Grice, it refers to the extra meaning that is not contained in the discourse but it is understandable only when the listener shares the knowledge of speaker, or we know why and how to intentionally violate one of the CP four criteria.

\subsection{Anti-heroic}

After 20th century, a kind of unique imageanti-hero appeared in literary works. Anti-hero is a summary of a new image created in modern literature. It doesn't mean the villain, but a general term for a class of characters with certain commonality in literary works (赖干坚, 1995). Their feature is anti-alienation. The appearance of anti-heroic images disintegrates the images of those heroes in people's impression, and the protagonists in the literary works are more and more ordinary, which is quite irrelevant to the character of the protagonists in the traditional novels. Meanwhile writers only focus on the most common persons: they are ordinary, inferior, and insignificant (薛燕, 2006). They show no concern of traditional morality and society. In their opinion, the so called power just is an immoral game, so they show indifference towards it. They often complain about the life, and show cynicism about the existing state of life, even they are very brutal, but their motivation is not evil. They lack the heroic qualities that the traditional protagonists have, and they stop being positive, fair-minded and brave. Sometimes they deny themselves and reject themselves (王岗, 2005). Anti-heroic images have become an important role in modern literary works. They resist the so called social norms of justice and 
equality, and at the same time they fight against the privileges and hypocrisy of the powerful and the old system through rebellion.

\section{CP Maxims Violation Contributing to Eggsy's Anti-heroic Characteristics}

\subsection{Violation of the Quality Maxim}

\subsubsection{By the use of the irony}

Example (1)

Friend A: "Foxes are vermin, guys. You should've driven it over"

\section{Eggsy: "I should've done a lot of things"}

Analysis (1)

By using the irony, Eggsy doesn't mean that he can do more, he is saying something himself believes to be false, so Eggsy is flouting the quality maxim. Eggsy is a little punk in the eyes of others, mixed with wine all day. At the very beginning, he quarrels with people in a bar, taking advantage of the theft of car keys. And he tries to crazily race car. Subsequently shuffling with the police on the road, he has a serious car crash in order to avoid a small fox. Then he was taken to the police station. The bold sentence he says doesn't mean he can do more, but to respond his friend's question. It shows that Eggsy cares for small animals and he is kindhearted.

Example (2)

Eggsy: "As my father saved your life even though you cost his life?What you've get him stuffed here also?”

Harry: “Can’t you see that what I have done has been about trying to repay him?”

Analysis (2)

This is the final dialogue between Eggsy and Harry. Eggsy shows his total dissatisfaction when he thinks that Harry kills his dog in order to get this job. He just can’t accept the fact that a person can do everything no matter it is unmoral for the purpose of realizing his goals. In this conversation, his statement is not true, he also knows that Harry knows it is false, so Eggsy violates the maxim of quality by the use of the irony, it shows that he is right-minded but still ill-considered.

\subsubsection{By the use of rhetorical question}

Example (3)

Harry: "Huge IQ, great performance in primary school, and it all went tits up. Drug, petty crime, never had a job.”

Eggsy: "Do you think there's a lot of jobs going around?"

Eggsy: "Yeah and when you grow up around someone like my stepdad, you pick up new hobbies pretty quick"

Analysis (3)

The above conversation is talked when Harry helps him get out of the jail. By the use of a rhetorical question, Eggsy violates the maxim of quality. Through reading Eggsy's files, Harry expresses his deep regret about Eggsy's giving up himself. Eggsy's response is full of irony, his stepdad is such a villain that he seems to be placing most of the blame on his stepdad. Initially what he shows to Harry is distrust, even disdain. Even though he is involved in a car crash with the police, and Harry helps him out of prison, Eggsy is still rude and 
doesn't want to talk too much to Harry. This mind-set of contempt for the power is a reflection of the little man's lack of ambition and repression in the harsh living environment, and is a kind of one-sided, blind understanding.

\subsubsection{By the use of telling lies}

Example (4)

Stepdad: "Who was with you in that fucking pub? I want to know the name of the geezer you were with."

Eggsy: "I was with no one. I don’t know what you're talking about.”

Analysis (4)

In the above conversation, what Eggsy says is not accord with the truth, so he is flouting the maxim of quality by the use of telling lies. Eggsy is just released by the police and talks with Harry in the coffee house, but a group of villains want to retaliate and fight with Eggsy. In the face of the provocation and entanglement of the villains, Harry appears to be extremely gentry, but the fact that high-tech weapons eventually has to be used to solve the problem violently shocks the self-righteous Eggsy.As soon as Harry is about to use the weapon of amnesia in order to make Eggsy forget that fight, Eggsy promises to keep it as a secret. After he goes back home, his stepdad is angry at his fighting with those villains and treats him violently. Even under his stepdad's domestic violence, Eggsy never tells the secret. It shows that Eggsy is a honest and reliable. He is a loyal young man who can do as he is asked, and who wants to do something good with his life.

Example (5)

Digby: "St. Andrews? Durham? Did you serve me at the McDonalds in Winchester Service Station?"

Eggsy: "No, but I heard that they give you an extra helping of secret sauce."

Analysis (5)

The above dialogue happens after falling out. A group of persons are living in so called ivory towers, graduate from the first-class universities, and they come from the rich families. In the eye of Eggsy, they are born with the silver spoon. At the very beginning, he just doesn't like them and refuses to get in touch with them. However, after talking with Harry, he changes his attitudes and begins to improve himself better. By telling lies, Eggsy is flouting the maxim of quality. Actually, he doesn't see Digby before. Even though they look down upon him and humiliate him through words, he does not feel angry, instead he tries to keep self-esteem.

\subsection{Violation of the Manner Maxim}

\subsubsection{By the use of displacing hearer}

Example (6)

Eggsy: “They are all Kingsman?”

Arthur: "Yes, our founder members. I want you to join me in a toast. To Galahad."

Eggsy: "Harry said you don't like to break the rules, often. Why now?"

Analysis (6) 
The above dialogue is between Eggsy and Arthur who is the head of Kingsman after Harry was killed. In a conversation with the head of Kingsman, Eggsy is so acute that he finds the fact that Arthur has become the follower of Valentine. By the use of changing talking subject and displacing hearer, Eggsy violates the maxim of manner in order to change two glasses of wine in a second, with one of which is being intoxicated. Finally he manages to escape the murder of Arthur. It can be said that in the secret service Eggsy was under the devilish training, which is different from the past experience in a violent family environment. This process of violence has not only made Eggsy a qualified agent at the physical and technical levels, but also makes him realize the importance of responsibility and the strength of the team. This conversation displays his professionalism as a Kingsman.

\subsubsection{By the use of prolix}

Example (7)

Eggsy: “No, please. I won't say anything. I swear,if there is one thing I can do, it's keep my mouth shut."

Harry: "Is that a promise?"

Analysis (7)

In the above dialogue, Eggsy violates the maxim of manner by the use of prolix. It happens after Harry has fought with a group of thugs who intend to take revenge on Eggsy. Harry tries to make Eggsy amnesiac, according to the regulations of Kingsman. Eggsy's answer is so long that it shows that he tries his best to make Harry entrust him. By the use of prolix, he spares no efforts to keep a secret. From his conversational implicature, we learn that he is honest.

\subsection{Violation of the Relation Maxim}

\subsubsection{By the use of changing the subject}

Example (8)

Policeman: "Now you can start giving me some names of the boys you were with...or you go down. It's up to you"

\section{Eggsy: "I want to exercise my right to a phone call"}

Analysis (8)

This dialogue happens between the policeman and Eggsy after a crash. In the car crash, he let his friends get out of the car and undertakes the whole responsibility. The policeman induces him to give the names of his partners, but Eggsy's answer is not related to the policeman's question. In the face of the reality that he will be possible to be put into prison, he calls Harry who has left the Warrior Medal and promises to help him at any time. He is finally released on bail under Harry's meditation. This part shows that Eggsy is a responsible and macho man. He loves his sister and takes care of his mother, and he is reliable even under the threat of the police, he doesn't tell the names of those boys who were with them in the cars at that time.

\section{Conclusion}

In the movie Kingsman, the protagonist is defined as an ordinary man with extraordinary life and great potential. Unlike the traditional hero, he is neither born in a family of professional agents, nor does he have the wealth or status of a distinguished family. Having made a deep analysis on the dialogues of Eggsy, the author 
of the thesis finds that Eggsy is a typical anti-hero on the basis of CP. The above chosen conversations reveal clearly that Eggsy's grown can be divided into three stages. Stage one reveals the ordinary and harsh situation of that little man. Initially, he is a street bum who is mixed with wine all the day. In stage two, after having conservation with Harry, his fighting spirit is aroused. With Harry's help over again and again, Eggsy begins to rediscover Harry and gradually changes his attitudes towards Harry. In the dangerous job interview of Kingsman, Eggsy shows extraordinary wit and cleverness. Compared with his companions who graduate from either Oxford University or Cambridge University, he is a totally little man suffering from exclusion and sarcasm. But finally he is one of the Kingsman who save the world. Stage three illustrates the metamorphosis from the little man to the great hero. Harry's death spurs Eggsy, so he decides to take up his weapon again and continues Harry's unfinished mission. Finally, he successes in smashing valentine's intrigues and saves the whole world.

In a word, the appearance of anti-hero images, whether from the aesthetic point of view or from the point of view of popular cultural tendency, has certain philosophical implications. Although they escape from reality, they also criticize reality, and both positive factors and negative factors are integrated into one. Through the creation of the anti-hero image, the writers express their deep concern for the whole real society. Anti-hero is the real hero in the new century. While CP gives us another way to analyze people's characteristics, what they say reflects their inner world. People may tell lies in the real life, but their violation of CP can reveal what they really mean. It does give us a new way of appreciating the literary works.

\section{References}

Gardner, R. (1995). Australian review of applied linguistics series: Conversation analysis: Some thought in its applicability to applied linguistics. Australian Review of Applied Linguistics Series. The Netherlands: John Benjamins Publishing Company.

Grice, H. P. (1975). Logic and conversation: Syntax and semantic. In P. Cole and J. Morgan (Eds.), Syntax and semantics, 3 , Speech Acts.

Levinson, S. C. (1983). Pragmatics. New York: Cambridge University Press.

VanDijk, J. A. (1976). Pragmatics and literature. Amsterdam: North-HollandPublishing Company.

徐丽红, 王桂亭. (2015). 论《一步之遥》的反讽艺术. 电影新作, (04).

戴炜栋, 何兆熊. (2002). 《新编简明语学教程》。上海: 上海外语教育出版社.

李琳. (2015). 《王牌特工: 特工学院》中的暴力美学. 电影文学, (08).

林晓娟. (2016). 马修・沃恩电影中的商业元素探析. 电影文学, (10).

田学军, 李圆臻, 吴秋佳, 邱玲. (2013). 英国维多利亚时期绅士文化研究. 西安建筑科技大学学报(社会科学版), (05).

胡壮麟. (1980). 《语用学》. 北京: 中国社会科学出版社. 